\title{
An Experimental Exploration of Diffuse and Specific Public Support for the EU in the Czech Republic*
}

\author{
ZUZANA RINGLEROVÁ** \\ Masaryk University, Brno
}

\begin{abstract}
As populism is becoming more widespread across Europe public support for political systems has moved to the forefront of public debates. One type of public support-diffuse support-is important for political systems because it provides a source of stability in times of crisis. The existing research on political support in nation-states shows that public support for the political community of the nation tends to be diffuse, while public support for other parts of the political system less so. Is there, like in nation-states, diffuse support for the political community of the European Union? This article argues that there is, and using data from a survey experiment in the Czech Republic finds that support for the political community of the EU is significantly more diffuse than support for the EU's institutions or incumbents. Public support for the political community of the EU thus serves the EU as a source of stability in times of crisis.
\end{abstract}

Keywords: political support, European Union, diffuse support, survey experiment, legitimacy

Sociologický časopis/Czech Sociological Review, 2019, Vol. 55, No. 3: 291-322

https://doi.org/10.13060/00380288.2019.55.3.468

Citizens' support for the European Union (EU) has long been a subject of scholarly attention. One important question researchers have asked is whether public support for the EU is tied to perceptions of the benefits that flow from EU membership or whether support for the EU is diffuse, that is, independent of how highly citizens rate the EU's performance. This is an important question because

\footnotetext{
* Acknowledgements: I thank Jay McCann, Naomi Levy, Tom Mustillo, Suzie Parker, Aaron Hoffman, Vlastimil Havlík, Petr Kaniok, Vratislav Havlík, and the three anonymous reviewers for their very helpful feedback on the earlier drafts of the manuscript. I thank the Purdue Research Foundation and the Department of Political Science at Purdue University for supporting this project. This project was supported by the Purdue Research Foundation's Research Grant (2014-2015) and by a Frank Wilson travel grant, awarded by the Department of Political Science, Purdue University, 2014.

** Direct all correspondence to: Zuzana Ringlerová, Department of International Relations and European Studies, Faculty of Social Studies, Masaryk University, Joštova 10, Brno 602 00, Czech Republic, e-mail: ringler@fss.muni.cz.
} 
the nature of public support affects how well the European Union as a political system deals with difficult events such as an economic crisis. A European Union that enjoys diffuse support from its citizens is more resilient to crises than a European Union that is supported by its citizens only when the citizens approve of the EU's policies [Dalton 2004; Norris 2011]. Given the outcome of the Brexit referendum and given the rise of populism across Europe, it is important to understand the nature of public support for the EU.

While research on public support for the EU does not provide a clear answer to the question about the nature of public support for the EU, research on public support in nation-states offers a more conclusive answer. Literature on public support in nation-states shows that political support can be described using a theoretical framework that divides political support into two types: specific and diffuse. While specific support fluctuates according to how much citizens like the current performance of the political system, diffuse support is unrelated to citizens' current views of the performance of the political system [Easton 1965; Dalton 2004; Norris 2011]. In addition, citizens tend to show this stable (diffuse) support only towards some objects within the national political system. For example, citizens' support for the political community ${ }^{1}$ of the nation tends to be fairly diffuse [Norris 1999]. In contrast, political support for regime institutions or incumbents is more specific.

Given the ability of diffuse support to remain stable even in times of crisis, when unpopular political decisions are often necessary, diffuse support is an important source of stability for political systems. Since there is no consensus in the existing literature on public support for the EU about whether there is diffuse support for the EU, this paper asks the following research question: Is there diffuse support for the political community of the European Union? In order to answer this question, I analyse original data from a survey experiment. The experimental treatment manipulated randomly selected individuals into a negative assessment of the EU's performance. This manipulation allowed me to observe how a negative change in attitude affects public support for different objects within the political system of the EU. The experiment thus allowed me to examine which objects within the political system of the EU enjoy diffuse support and which objects enjoy specific support.

I find that there is a causal relationship between perceptions of the EU's performance and support for the EU. This causal relationship, however, exists only for some dimensions of political support for the EU. While support decreases for both the political regime and for the regime authorities as performance evaluations decline, support for the political community does not decrease. Based on these findings I argue that there is diffuse support for the political community

\footnotetext{
${ }^{1}$ Support for the political community is defined as the 'basic attachment to the nation beyond the present institutions of government and a general willingness to co-operate together politically' [Norris 1999: 10].
} 
of the EU. I further argue that support for the supranational political system of the EU fits the same theoretical framework as political support in nation-states. Like in nation-states, there are two types of political support: specific and diffuse. Support for the political community of the EU is diffuse while support for regime institutions and incumbents is more specific. This implies that-like in nation-states - public support for the political community of the EU is not easily swayed by momentary negative public perceptions of the EU's performance and that public support constitutes a source of stability for the EU in times of crisis.

\section{Concepts, literature review, and hypothesis}

The concept of political support is defined as individuals' favourable attitudes towards an object that represents the political system. The literature on political support in nation-states distinguishes three broad categories of objects towards which individuals may direct their political support: the political community, the political regime, and the political authorities [Easton 1965; Norris 1999; Dalton 2004]. These three categories of objects define the 'dimensions' of political support. The first dimension-support for the political community-represents political support at the most basic level. It is defined as a 'basic attachment to the nation beyond the present institutions of government and a general willingness to co-operate together politically' [Norris 1999: 10]. The second dimension-support for the political regime-represents attitudes towards the 'constitutional order of a nation' [Dalton 2004: 6]. This includes support for regime principles, norms, and procedures, as well as support for regime institutions. The third dimension of political support-support for political authorities-is defined as support for the politicians who are currently in office [Easton 1965; Norris 1999; Dalton 2004].

In addition to distinguishing between the three dimensions of political support, the theoretical literature on political support in nation-states distinguishes between two types of political support: specific and diffuse [Easton 1965; Dalton 2004; Norris 2011]. Specific support is performance-based. In other words, it is a 'running-tally' type of attitude, tied to the political system's performance. If individuals are not satisfied with the performance of the political system, they lower their specific support. In contrast, diffuse support is not a 'running tally', it is an affective attitude. If individuals harbour diffuse support for a political object, they support the object for its own sake, independent of what they think about the political object's performance. Therefore, diffuse support remains stable even if citizens become less positive about how well the political system is performing. ${ }^{2}$

\footnotetext{
${ }^{2}$ Over a long period of time, however, an accumulation of negative performance evaluations can undermine diffuse support as well. Similarly, an accumulation of positive performance evaluations is expected to help build up diffuse support.
} 
The dichotomy between specific and diffuse support is related to other frameworks that have been used to study positions towards the EU. Taggart and Szczerbiak [2004] distinguish between 'hard' and 'soft' Euroscepticism. By rejecting the entire project of European integration, hard Euroscepticism is similar to a lack of diffuse support. Soft Euroscepticism, as qualified opposition to the EU, is similar to a lack of specific support. Kopecky and Mudde [2002] have also designed a framework related to the concepts of diffuse and specific support. This framework has two dimensions. The first dimension draws on the concept of diffuse support and refers to the level of support for the idea of European integration. The second dimension relates to the concept of specific support and refers to support for the EU as an actual (not ideal) political entity. By combining these two dimensions into a two-by-two framework, the authors create four ideal types of Euroscepticism.

Both of these frameworks are valuable tools in the study of Euroscepticism in political parties. They are less suitable, though, for the study of Euroscepticism in individuals. Although there are similarities in how individuals and parties think about the EU, there are important differences. Political parties are institutions. Individuals, on the other hand, are human beings with emotions and cognitive processes that are different from the way institutions work. For example, although parties are composed of individuals, we would not expect a political party to form an affective attachment to a political institution. In contrast, it is reasonable to expect an individual to form an affective attachment to a political institution. For these reasons, I have opted for the diffuse vs specific framework rather than for the typologies of Euroscepticism that were developed in the context of research on political parties.

The dichotomy between specific and diffuse support refers, in essence, to a distinction between performance-based and affective political support. Although this distinction between performance-based and affective support is common in the literature on political support, the dichotomy sometimes appears under different labels. Specific support is called 'evaluative' by Russell Dalton [2004] and 'utilitarian' by Lindberg and Scheingold [1970]. Diffuse support is sometimes called 'affective support' [Lindberg and Scheingold 1970; Almond and Verba 1963]. David Easton's terminology of diffuse and specific support is most common in the general comparative literature on political support, as well as in the more recent literature on support for the European Union. I therefore use Easton's terminology.

The literature on political support in nation-states combines the distinction between diffuse and specific support with the notion of three dimensions of political support into one theoretical framework [Norris 1999]. According to this framework, dimensions of political support are ordered according to their positions on the diffuse-specific spectrum. Figure 1 shows how the three dimensions of political support are placed on the diffuse-specific scale. Support for the political community is the most diffuse dimension. Support for the political community is therefore fairly resistant to individuals' dissatisfaction with the workings 
Figure 1. Position of the three dimensions of political support on the diffuse-specific scale

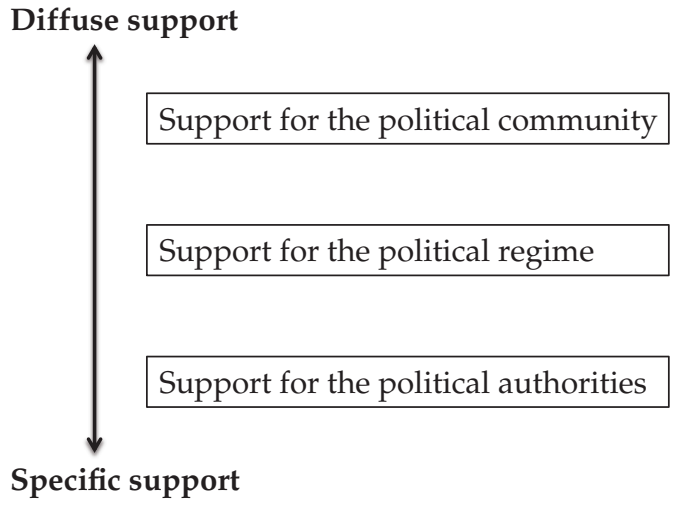

Note: This figure is a simpler version of a similar figure in Norris [1999: 10].

of the political system. Support for the political regime, including support for regime institutions, lies further from the diffuse end of the spectrum. This means that support for the political regime has a stronger performance-based component. The last dimension-support for incumbents-is located close to the specific end of the spectrum. This dimension of political support is therefore most closely related to the performance of the political system.

This conceptual framework represents public support in national political systems fairly well [Norris 1999]. But how well does this framework travel from the national level to the supranational level? In other words, is there diffuse support for the political community of the EU just as there is diffuse support for the political community of a nation-state? The existing literature provides little guidance on these questions.

The extant literature on support for the EU includes attempts to identify distinct dimensions of support for the EU. Boomgaarden et al. [2011] identify five dimensions of EU-related attitudes: negative affection, identity, performance, utilitarianism, and strengthening. While negative affection represents fear of European integration's effects on national culture, the identity dimension captures identification with the EU. The performance dimension evaluates the functioning of European institutions and utilitarianism pertains to the individual's perceived benefits from EU membership. The strengthening dimension captures individuals' attitudes towards deeper integration of the EU. Although these five distinct dimensions of EU-related attitudes are informative, they do not fully answer the question about dimensions of political support. This is because the five dimensions include a greater range of attitudes, not just attitudes regarding political 
support. It therefore remains unclear to what extent the concept of political support for the EU is similar to political support in nation-states.

Studies that focus specifically on the question of the diffuse or specific nature of public support for the EU find that political support for the EU is both specific and diffuse. Several studies show that support for the EU-usually measured as support for EU membership-is related to benefits flowing from EU membership. Aggregate-level studies show that support for the EU is higher in countries that are net receivers of funds from the EU budget [Hooghe and Marks 2004] and in countries that depend significantly on the European Union as their export market [Eichenberg and Dalton 2007]. Macroeconomic indicators also seem to play a role. Support for the EU tends to be higher in countries with higher GDP growth and lower unemployment rates [Eichenberg and Dalton 1993; Mahler et al. 2000; Eichenberg and Dalton 2007]. A correlation between benefits received and support for the EU has also been found at the individual level of analysis. Individuals who work in occupations that benefit from the integration of the European market are more supportive of the EU [Gabel 1998; Hooghe and Marks 2004]. Similarly, respondents who have a positive view of the economy are more supportive of the EU [Anderson 1998; Gabel 1998; Carey 2002; de Vreese and Boomgaarden 2005; Hobolt and Tilley 2014]. In addition, individuals who think that the EU benefits their country or themselves personally tend to show stronger support for the EU [Gabel and Palmer 1995].

More recent studies argue that support for the EU is tied to individuals' identity and therefore has a strong diffuse component. Multiple studies show that individuals with an exclusive national identity show lower support for the EU [Carey 2002; McLaren 2002; Hooghe and Marks 2004; Serricchio et al. 2013]. Studies examining support for the EU over time show that there is a significant level of stability over time, indicating that support for the EU is diffuse in nature [Beaudonnet and Franklin 2014; Ringlerova 2015].

Although this is a large volume of work, there is no systematic study of which dimensions of public support for the EU are more specific and which are more diffuse. In addition, much of the existing work uses observational research designs. An observational research design is a suboptimal tool for answering the question about the diffuse or specific nature of support for the EU. Observational research designs do not allow researchers to conclusively establish whether support for the EU varies based on changes in perceptions of the political system's performance. Furthermore, an observational research design makes it difficult to tell whether some dimensions of political support are more sensitive to changes in performance than others. In this study I overcome these limitations by using an experimental research design.

Experiments are a powerful research tool in the study of causal relationships because they effectively control for confounding variables. In an observational research design we can never rule out the possibility that the observed correlation is just a correlation, not a causal effect. In experiments, however, we can control for all confounding variables through the random assignment of subjects into treat- 
ment groups. Therefore, if a change in the dependent variable is observed, we know that the experimental treatment is the source of the change. An experimental research design thus allows me to determine whether there is a causal relationship between perceptions of performance on one hand and different dimensions of support for the EU on the other. In addition, it allows me to establish whether this causal relationship is stronger for some dimensions of support than others.

As explained above, political support in nation-states has three dimensions. Of these three dimensions, support for the political community is the most diffuse, support for the political regime is moderately diffuse, and support for the incumbents is the least diffuse. It is unclear whether support for the EU has the same structure as support in nation-states. It is the aim of this paper to examine whether support for the EU has the same structure as political support in a nation-state. Specifically, the aim is to determine whether, as in a nation-state, the quality of political support varies depending on whether the support is directed at the political community, the political regime, or the incumbents.

Given the existing research, the expectations for the analysis can go both ways. The structure of political support for the EU can be expected to be similar to, as well as different from, the structure of political support in nation-states. There are reasons to expect public support for the EU to have the same structure as public support in nation-states. The EU, like a nation-state, has symbols, such as a flag and an anthem, that allow citizens to form an affective attachment to the political system of the EU. Citizens encounter the flag in everyday life as it often appears on government buildings. Czech citizens also see EU symbols on their health insurance card and driver's license, which are frequently used personal documents. Being exposed to symbols of the EU increases the feeling of European identity [Bruter 2009]. Since identity is an affective attitude, it may be viewed as a form of diffuse support for the EU. At the same time, existing literature shows that some dimensions of public support for the EU are related to performance [Anderson 1998; Gabel 1998; Carey 2002; de Vreese and Boomgaarden 2005; Hobolt and Tilley 2014]. It is therefore possible that political support for the EU will fit the framework developed in the research on public support in nationstates; a framework where support for the political community is the most diffuse, support for the political regime is moderately diffuse, and support for the incumbents is the least diffuse.

However, there is also reason to believe that public support for the EU will be different from public support in nation-states. First, some studies argue that due to limited knowledge about the European Union, EU citizens do not distinguish between different objects of support [Torcal et al. 2012; Duchesne et al. 2013]. According to these studies, support for the EU is one broad attitude encompassing all aspects of the EU. If this is the case, political support for the EU will be different from political support at the national level. The three dimensions of support for the EU will not differ in the extent to which they are diffuse.

Second, public support for the political community of the EU is likely to be much less diffuse than public support for the political community of a nation- 
state. In a nation-state, public support for the political community is the most diffuse dimension of political support. This is not surprising since individuals learn about their belonging to a nation-state early in life. Later, through education and political learning, the existence of their nation-state becomes a firmly formed fact of the political reality around them [Carter and Teten 2002]. Although individuals are citizens of the European Union in a similar way as they are citizens of their nation-states, the EU is not as visible in their lives as the nation-state. Individuals' support for the political community of the EU is therefore likely to be much weaker and less stable than their support for the political community of the nation-state. We may therefore expect that citizens' support for the political community of the EU will be less stable and more tied to current regime performance than is the case in nation-states.

In sum, this paper uses a novel technique to examine whether there is diffuse public support for the political community of the EU. There are reasons to believe that, as in a nation-state, there will be diffuse support for the political community of the EU. The first hypothesis therefore posits that political support for the EU will have the same structure as political support in a nation-state. In other words, the first hypothesis expects that support for the political community will be least tied to citizens' perceptions of EU's performance, support for the political regime will be moderately tied to perceptions of performance, and support for incumbents will be tied most to perceptions of performance. However, there are compelling reasons to believe that the foundations for public support for the $\mathrm{EU}$ are much weaker than the foundations of public support in nation-states and that, unlike in a nation-state, there is little diffuse support for the EU. Given these less firm foundations of public support for the EU, the second hypothesis posits that public support for the political community of the EU will be significantly influenced by citizens' perceptions of the EU's performance. In other words, the second hypothesis expects that there will be a causal relationship between citizens' perceptions of EU performance on one hand and all three dimensions of support for the EU on the other.

\section{Data and variables}

I examine the question of whether there is diffuse support for the political community of the European Union by analysing data from a survey experiment. The experiment exposed randomly selected individuals to unfavourable information concerning the President of the European Commission. This manipulation led to more negative assessments of the European Union, relative to individuals in the control group. The experimental manipulation allowed me to observe how such a negative change in attitude affects the stability of various dimensions of support for the EU.

The experiment was conducted in the Czech Republic. Although the data were collected only in this one EU member state, there are indicators suggesting 
that the results might be consistent with other EU member states. First, the Czech Republic provides a hard case for examining the stability of different dimensions of support for the EU. The Czech Republic stands out among EU member states as it has a lower level of support for the EU [Eurobarometer 2015]. This fact, however, should not significantly influence the substantive conclusions from the present analysis. The goal of this analysis is to examine how much change occurs in different dimensions of political support as a result of an experimental treatment. An overall lower level of political support in the population provides less 'room' for a decrease in support. This makes it less likely that significant differences in resistance to the negative treatment would be found between different dimensions of political support. Conducting this kind of survey experiment in an environment with lower than average overall support thus makes it more difficult to find any significant differences in resilience between different dimensions of political support. It is therefore likely that conducting this experiment in EU member states with higher overall support for the EU would find equal or more pronounced differences in resilience between different dimensions of political support. It is therefore reasonable to infer that findings from the Czech context will be indicative of European public attitudes more generally.

Second, even though the Czech Republic is one of the newer members of the European Union, it has been a member since 2004. By 2015, when the data collection took place, the Czech Republic had been an EU member for more than 10 years. It is therefore unlikely that the novelty of EU membership affected the results of the analysis.

Third, the Czech Republic is a fairly typical member state with regard to the relationship between the national and the European levels of government. The results of the experiment therefore should not be influenced by anything specific about the relationship between the Czech government and European governing institutions. Between 2004 and 2015, this relationship had been neither unusually confrontational nor exceptionally friendly. The only exception to this trend was the strongly Eurosceptic position espoused by Czech President Václav Klaus, who held office between 2003 and 2013. The role of the Czech president, however, is largely ceremonial. The principal holder of the executive power-the national government-did not share this confrontational anti-EU stance. Nevertheless, unlike many other EU member states, the Czech Republic has had at least two significant Eurosceptic political parties (the Civic Democratic Party and the Communist Party of Bohemia and Moravia). It is possible that the rhetoric of these parties has made citizens more receptive to Eurosceptic arguments compared to the citizens of EU member states without strong Eurosceptic parties. If this is the case, the results of this study will be generalisable only to EU member states with established Eurosceptic elites.

The experiment was conducted via a brief internet-based public opinion survey. In total, 206 individuals volunteered to take part in the survey. Data col- 
Sociologický časopis/Czech Sociological Review, 2019, Vol. 55, No. 3

\section{Table 1. Sociodemographic characteristics of the sample}

\begin{tabular}{|c|c|c|}
\hline & Frequency & Percent \\
\hline \multicolumn{3}{|l|}{ Gender } \\
\hline Male & 96 & 46.6 \\
\hline Female & 107 & 51.9 \\
\hline Missing & 3 & 1.5 \\
\hline Total & 206 & 100.0 \\
\hline \multicolumn{3}{|l|}{ Place of residence } \\
\hline Rural & 43 & 20.9 \\
\hline Small town & 56 & 27.2 \\
\hline Urban & 104 & 50.5 \\
\hline Missing & 3 & 1.5 \\
\hline Total & 206 & 100.0 \\
\hline \multicolumn{3}{|l|}{ Age } \\
\hline $18-24$ & 25 & 12.1 \\
\hline $25-34$ & 89 & 43.2 \\
\hline $35-44$ & 45 & 21.8 \\
\hline $45-54$ & 22 & 10.7 \\
\hline $55-64$ & 15 & 7.3 \\
\hline $65<$ & 4 & 1.9 \\
\hline Missing & 6 & 2.9 \\
\hline Total & 206 & 100.0 \\
\hline \multicolumn{3}{|l|}{ Education } \\
\hline No high school & 2 & 1.0 \\
\hline High school & 39 & 18.9 \\
\hline Some college & 22 & 10.7 \\
\hline College & 139 & 67.5 \\
\hline Missing & 3 & 1.5 \\
\hline DK & 1 & 0.5 \\
\hline Total & 206 & 100.0 \\
\hline
\end{tabular}


lection took place in the Czech Republic in February and March 2015. ${ }^{3}$ Potential respondents were contacted through e-mails, social media postings, and flyers. Respondents were recruited among non-academic employees of Masaryk University in Brno and among the population outside the university. Although the resulting sample is not a random sample, it is diverse in terms of age, gender, educational attainment, and in terms of the respondents' place of residence. Table 1 provides additional information on the sample. Randomisation checks confirm that the experimental groups are balanced with respect to all major demographic traits and a wide array of political attitudes. ${ }^{4}$

The experiment took the form of a two-group post-test-only randomised experiment..$^{5}$ The experimental survey questionnaire was structured as follows: First, respondents answered various questions concerning their sociodemographic background. Then each respondent was randomly assigned to either the treatment group or the control group (100 individuals in the treatment group, 106 individuals in the control group). Individuals in the treatment group read a brief article about a financial scandal regarding Jean-Claude Juncker, the President of the European Commission. Individuals in the control group read an article about the process by which a new European Commission takes office. Both the treatment text and the placebo text identified Mr Juncker as the President of the Commission and mentioned Mr Juncker and the European Commission an equal number of times. Both news articles drew on information from online media outlets, and they resembled the style of a news article published on an online news website. The information conveyed to the respondents in both the treatment text and the placebo text was factually accurate.

After reading the article, respondents were asked to write down 2-3 words that characterise the article. This item served as a treatment validation exercise. Individuals in the treatment condition tended to choose negative words such as 'corruption' or 'tax evasion'. Respondents in the control group provided neutral statements such as 'new European Commission', 'election', or 'appointment'. Table 2 shows the distribution of negative, positive, and neutral comments in the treatment and control groups. The prevalence of negative statements provided by respondents in the treatment group shows that the treatment was successful in manipulating the respondents into negative thoughts about the functioning of the European Union.

\footnotetext{
${ }^{3}$ Data collection took place before the European immigration crisis of 2015 became a frequent topic in the news.

${ }^{4}$ I tested for the equality in distribution of gender, age, education, interest in national political matters, interest in European political matters, and left-right ideology. None of these tests shows a statistically significant difference between the treatment group and the experimental group (for details, see Table A in the Appendix).

5 This experimental design does not include pre-test measurement of the dependent variable. Random assignment makes the treatment group and the control group equivalent and is thus enough to control for all possible confounding variables.
} 
Table 2. The percentage of different types of write-in statements: a comparison of the treatment group and the control group

\begin{tabular}{lccccc}
\hline & Negative & Positive & Neutral & Missing & Total \\
\hline Treatment group & 78 & 0 & 18 & 4 & 100 \\
Control group & 8.5 & 1 & 75.5 & 15 & 100 \\
\hline
\end{tabular}

Table 3. Details on variables measuring political support for the EU

\begin{tabular}{|c|c|}
\hline Variable name & Description \\
\hline & $\begin{array}{l}\text { Please, use the following scale from } 0 \text { to } 10 \text {, where } 0 \text { means } \\
\text { 'Don't trust at all' and } 10 \text { means 'Fully trust', and tell us } \\
\text { how much you trust the following institutions: }\end{array}$ \\
\hline Trust: Juncker & President of the European Commission Jean-Claude Juncker \\
\hline Trust: Eur. Commission & European Commission \\
\hline Trust: Eur. Parliament & European Parliament \\
\hline Trust: EU & $\begin{array}{l}\text { How often do you believe the European Union acts in the } \\
\text { interest of its citizens? Almost always/Usually/Only some- } \\
\text { times/Almost never/Never/DK }\end{array}$ \\
\hline $\begin{array}{l}\text { Support: } \\
\text { EU membership }\end{array}$ & $\begin{array}{l}\text { Generally speaking, do you think that the Czech Republic's } \\
\text { membership of the European Union is...? a very good } \\
\text { thing/a good thing/neither a good or bad thing/a bad } \\
\text { thing/a very bad thing/DK }\end{array}$ \\
\hline Feeling an EU citizen & $\begin{array}{l}\text { Do you feel you are a citizen of the European Union? Yes, } \\
\text { definitely/Yes, to some extent/No, not really/No, definitely } \\
\text { not/DK }\end{array}$ \\
\hline
\end{tabular}

Note: All variables were recoded to range from 0 to $1(0=$ low support, $1=$ high support $)$.

Measurement of the dependent variable (support for the EU) immediately followed the treatment validation. Six variables were used to measure support for the EU. ${ }^{6}$ Support: EU membership represents individuals' attitudes towards the Czech Republic's membership in the EU. Variables Trust: Juncker, Trust: Eur. Commission, and Trust: Eur. Parliament indicate how much trust the respondent has in the respective political objects. In the survey item named Trust: EU, respondents expressed how much they believed that the EU acts in the interest of its citizens.

${ }^{6}$ In order to avoid question-order effects, the items measuring support for the EU were randomly rotated. 
And finally, Feeling an EU citizen indicates the extent to which the respondent thought of herself as a citizen of the EU. All measures of support for the EU were recoded to range from 0 to 1 , with higher values indicating greater support.

The purpose of the analysis is twofold: first, to establish whether there is a causal relationship between perceptions of the EU's performance and support for the EU; and second, to establish whether the three dimensions of support for the EU (support for the community, regime, and authorities) differ in their vulnerability to negative performance evaluations. The survey measures all three dimensions of political support. Support for the EU as a political community is represented by individuals' reported feeling of European citizenship (Feeling an EU citizen), support for EU membership (Support: EU membership), and trust in the EU (Trust: EU). Citizens' support for the political regime of the EU (including regime institutions) is measured by trust in the European Commission and the European Parliament (Trust: Eur. Commission and Trust: Eur. Parliament). Trust in Mr Juncker (Trust: Juncker) measures support for incumbents.

\section{Analysis}

\section{Basic analysis of the treatment effect}

The analysis below explores how well the experimental manipulation affects individuals' support for the European Union. In other words, the analysis explores the extent to which different dimensions of support for the EU are influenced by negative information about the EU. This experimental manipulation is a tool that allows me to determine how stable various dimensions of support for the EU are when challenged by negative evaluations of how well the EU works. Diffuse support is an affective attitude and it is unrelated to momentary changes in evaluations of the regime's performance. We can expect that diffuse dimensions of support will therefore remain resistant to the treatment effect. In contrast, specific support is tied to evaluations of regime performance. We may therefore expect that specific dimensions of support for the EU will be significantly affected by the treatment.

A $t$-test is used to evaluate the difference in average political support between the treatment group and the control group. The results of the $t$-test are reported in Table 4 . As a robustness check for the $t$-test analysis, I analysed the data using a multivariate regression controlling for political sophistication. The results of the multivariate regression are reported in Tables B and C in the Appendix. The results of the robustness check are substantively equivalent to the results of the $t$-test presented in the following paragraphs.

The first line of results in Table 4 shows that the treatment had the greatest effect on trust in the President of the European Commission. Individuals in the experimental group evidenced an average amount of trust in Mr Juncker that was 
Table 4. The effect of the treatment on various dimensions of support for the EU: comparing the treatment group and the control group

\begin{tabular}{lccc}
\hline $\begin{array}{l}\text { Dimension of political } \\
\text { support }\end{array}$ & $\begin{array}{c}\text { Average difference } \\
\text { between the two groups }\end{array}$ & s.e. of the difference & $\mathrm{N}$ \\
\hline Trust: Juncker & $.19^{* *}$ & 0.04 & 144 \\
Trust: Eur. Parliament & $.09^{*}$ & 0.04 & 177 \\
Trust: Eur. Commission & $.09^{*}$ & 0.04 & 174 \\
Support: EU membership & 0.05 & 0.04 & 192 \\
Feeling an EU citizen & 0.04 & 0.05 & 196 \\
Trust: EU & $.13^{* *}$ & 0.04 & 198 \\
\hline
\end{tabular}

** $p<0.01 ;{ }^{*} p<0.05$. Results of the $t$-tests. Only the variable Trust: EU has unequal variances between the two groups. The results are not substantively different if only the observations with no missing data on all measures of support are used.

.19 lower than in the control group. Given that all the political-support variables range from 0 to 1 , this is a fairly large effect. Thus, there appears to be a fairly strong causal relationship between perceptions of political system's performance on one hand and trust in incumbents on the other.

The second and third lines of results in Table 4 show that public support for regime institutions is affected to a lesser extent by the treatment than support for incumbents. Compared to a 19 drop in political support for incumbents, support for the European Commission and the European Parliament dropped by only .09 points. These results show that there is a causal relationship between perceptions of the EU's performance and support for regime institutions. This causal relationship, however, is weaker than in the case of support for incumbents. Thus, support for incumbents is less diffuse and more specific than support for regime institutions.

The last part of Table 4 shows the strength of a causal relationship between perceptions of the EU's performance and support for the political community of the EU. As the fourth and the fifth lines in Table 4 show, individuals' support for EU membership and a feeling of European citizenship are both highly immune to changes in evaluations of the EU's performance. For these two variables, the difference between the experimental group and the control group is small, and it is not statistically significant. This shows that there is no systematic causal relationship between perceptions of the EU's performance on one hand and support for EU membership or a feeling of European citizenship on the other. Given their resistance to changes in perceptions of the EU's performance, support for membership and a feeling of EU citizenship are two diffuse dimensions of support.

In contrast, the variable measuring individuals' belief that the EU acts in the interests of its citizens is not immune to the effect of the treatment. The effect of 
the treatment is quite large (.13) and statistically significant. Although the magnitude of the effect is smaller than in the case of trust in Mr Juncker, it is larger than in the case of trust in EU institutions. This implies that a variable measuring individuals' belief that the EU works in the interest of its citizens does not indicate diffuse support for the EU. It may be that the wording of the question directs respondents towards an evaluation of how well the EU works, instead of measuring political support. Although individuals' trust in the EU is not as resistant as expected to the negative experimental treatment, there are dimensions of support for the political community of the EU that show high resistance to the negative treatment. Thus, the results show that there is diffuse support for the European Union. This diffuse support is represented by individuals' support for EU membership and by their feeling of European citizenship.

\section{Does the magnitude of the treatment effect depend on respondents' characteristics?}

Existing research shows that the effects of experimental treatments may vary by the particular characteristics of the respondent. Drawing on the work of John Zaller [1992], many studies indicate that the impact of new information on attitudes varies by level of political sophistication [de Vreese 2004; de Vreese et al. 2011]. To explore whether political sophistication conditions the effect of the treatment in this study, a series of OLS regression models was estimated to test for an interaction between the treatment and political sophistication. ${ }^{7}$ A large regression coefficient for the interaction terms will indicate that the size of the treatment differs based on the level of respondents' political sophistication. Political sophistication is measured in two ways: by educational attainment and by political knowledge. Operational definitions of these two variables and definitions of the other independent variables used in this section are provided in Table D in the Appendix. The results of the estimations focusing on political sophistication are reported in Tables 5 and 6 . Neither of the reported models shows a statistically significant interaction between the treatment and political sophistication. This means that political sophistication does not moderate the effect of performance evaluations on support for the EU.

In order to learn more about the effect of the treatment, I further explored whether the size of the effect varies depending on individual characteristics such as age, gender, left-right ideology, and political interest. Again, a set of OLS regression models with interactions between the treatment and the respective individual

\footnotetext{
${ }^{7}$ I re-estimated all the OLS regressions presented in this chapter using the Tobit model [Long 1997]. A Tobit model is appropriate for censored data (censored data have only a limited range for the values of the dependent variable, as in the present case in which the value of the dependent variable ranges from 0 to 1 ). Re-estimating the OLS regressions using Tobit did not show any substantive differences in the results.
} 
Sociologický časopis/Czech Sociological Review, 2019, Vol. 55, No. 3

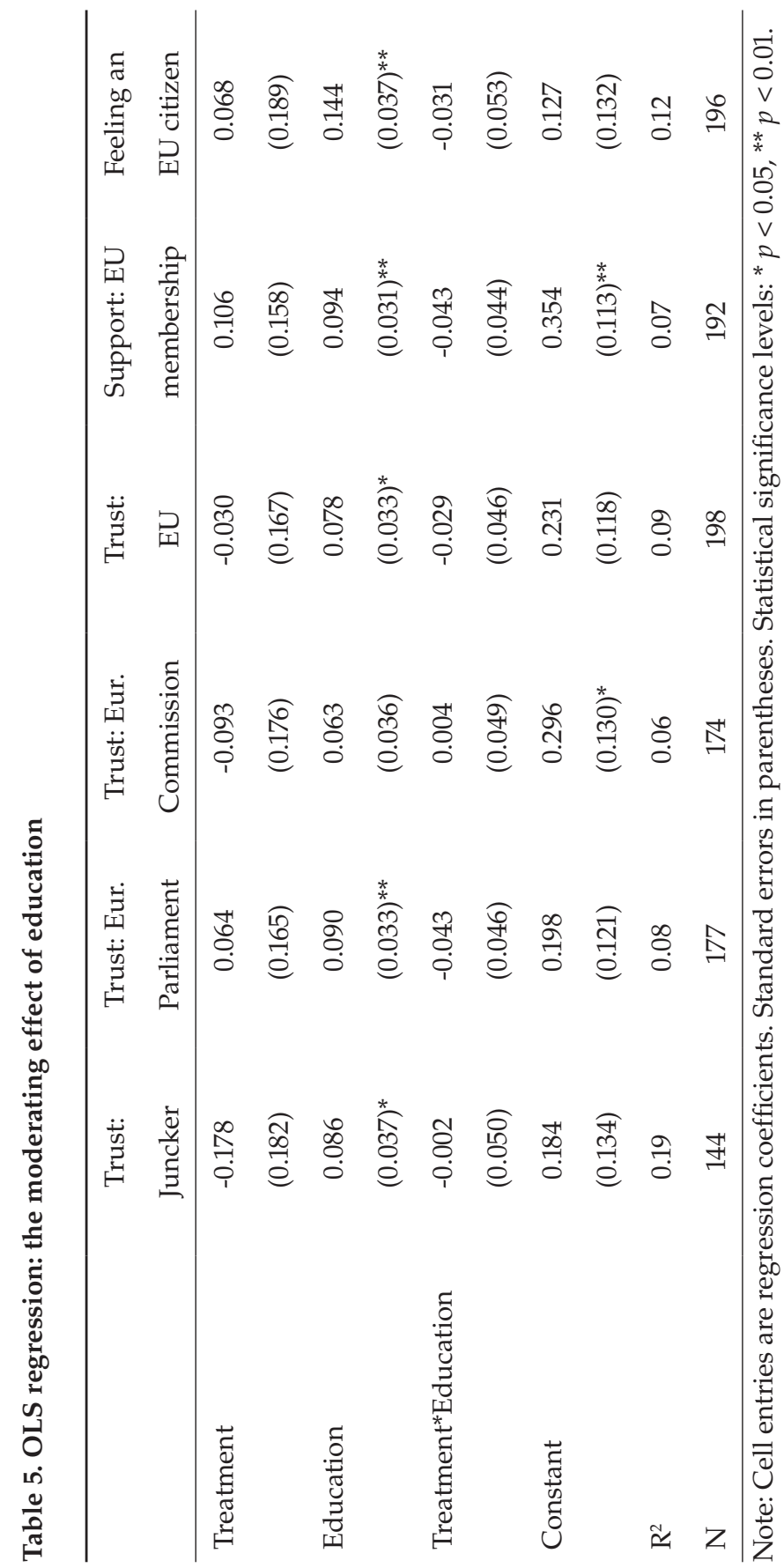




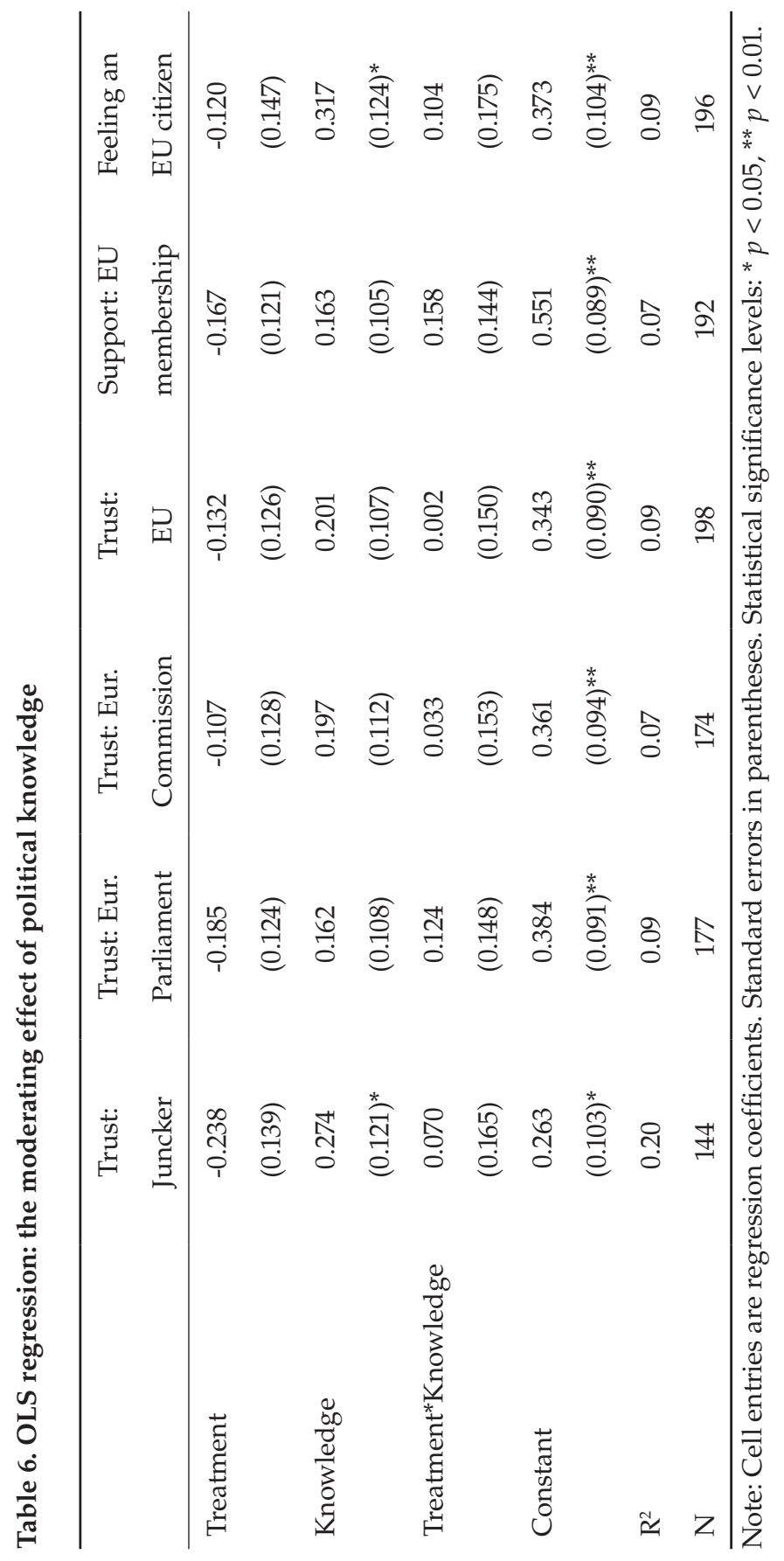


characteristic was estimated. The results of these estimations are reported in Tables E - I in the Appendix. The models show that the effect of the treatment does not vary depending on age, gender, ideology, or political interest.

\section{Conclusion}

This study contributes to the current debates about the future of the European Union. The Brexit referendum showed how important mass public diffuse support for the European Union is and how serious the consequences can be if such support is lacking. Given the rise of populism across Europe, including calls for more referendums to exit the EU, it is of primary importance to understand the nature of mass public support for the EU. This paper has addressed this issue by examining whether there is diffuse support for the political community of the European Union. It took nation-states as a template. In nation-states political support has three major dimensions and each dimension is diffuse to a different degree. Support for the political community is the most diffuse, support for the political regime is moderately diffuse, and support for incumbents is the least diffuse. In this paper, I have explored whether there is diffuse support for the EU similar to the way there is for a nation-state. Based on evidence from a survey experiment, I argue that there is diffuse support for the political community of the European Union.

I evaluated whether there is diffuse support for the EU by looking at the strength of the causal relationship between a change in perceptions of the EU's performance on one hand and different dimensions of support for the EU on the other. Since diffuse support is defined as political support that remains stable even when perceptions of performance change, an absence of a causal relationship between performance and support indicated diffuse support. I found that there is a fairly strong causal relationship between perceptions of EU performance and support for incumbents. This dimension of support for the EU is thus the least diffuse. Support for EU institutions as well as trust in the EU display a moderate strength of dependence on perceptions of EU performance. These dimensions of support for the EU are thus moderately diffuse. The next two dimensions, Feeling a European citizen and Support for EU membership, both exhibit a high level of immunity to changes in perceptions of the EU's performance. Therefore, these two attitudes represent diffuse support for the political community of the EU.

The experimental approach used in this paper is a novel way of addressing the question whether there is diffuse support for the EU. To my knowledge, no previous study has applied rigorous experimental methods to this research question. Further work, and especially experimental work, is required due to the inherent limitations of the present study. This study bases its evidence on a sample of convenience. Nevertheless, the sample was diverse in terms of all demographic characteristics. Although it does not satisfy the standards of a nationally repre- 
sentative sample, it allows us to observe how the treatment affects individuals who are diverse in terms of age, income level, education, and other characteristics. In addition, in contrast to many EU member states, the political party system of the Czech Republic has for a long time included significant Eurosceptic elites. It may be the case that the presence of these Eurosceptic elites in the political arena leads to a different structure of public support for the EU compared to countries without developed Eurosceptic elites. Future research may determine whether the presence of Eurosceptic elites matters for the structure of public support for the EU. This study lays the groundwork for future research, which may conduct similar types of experiments on nationally representative samples in the Czech Republic as well as in other EU member states.

In addition, this study is a first step in exploring how different types of challenges to public support of the EU affect support for the EU. This study explored how reports about possible corruption of a major European office-holder affect different dimensions of support for the EU. Further work is needed to explore how other types of challenges, such as information about the lack of democratic oversight in the EU or evaluations of specific EU policies, affect different dimensions of support for the EU. This will provide a more complete picture of diffuse and specific support for the EU.

Overall, this paper shows that there is a causal relationship between evaluations of how well the EU is working and support for the EU. This causal relationship, however, exists only for some dimensions of political support. While support for both the political regime and for regime authorities decrease as a result of a decline in performance evaluations, support for the political community does not decrease. This paper thus demonstrates that, as in the case of political support in the context of nation-states, support for the EU has three distinct dimensions and that these three dimensions occupy different positions on the diffuse-specific scale. Importantly, this paper shows that there are dimensions of support for the EU that are highly resistant to negative perceptions of EU performance. This is good news for the European Union. It implies that the European Union can use this 'reservoir of favourable attitudes or good will' [Easton 1965: 273] as a source of resilience in times of crisis.

Nevertheless, the empirical finding that there is diffuse support for the political community of the EU does not mean that diffuse support is forever stable. Although Easton's framework of political support does define diffuse support as the kind of support that does not sway according to momentary changes in the evaluations of how well the political system works, diffuse support may vary in the long term. Long-term exposure of individuals to negative information about the EU will, over time, decrease diffuse support for the EU. Similarly, long-term exposure to positive evaluations will increase diffuse support for the EU. Michael Bruter's experimental study [Bruter 2009], for example, showed that long-term exposure to positive or negative information about the EU affects the level of individuals' European identity. This effect, however, is not immediate and man- 
ifests only over a longer period of time. Diffuse support for the EU therefore provides the EU with a source of resilience in times of crisis when resources are scarce, when citizens may be asked to share the burden of the crisis, and when, as a result, citizens' evaluations of regime performance decrease. However, this source of resilience may be gradually reduced if dissatisfaction with the regime's performance lasts over a long period of time. Therefore, if citizens are exposed to consistently negative messages about the EU, for example from populist parties, diffuse support may decrease over time. However, positive perceptions of how well the political system functions should work towards building up diffuse support. If populist Eurosceptic messages are countered with positive messages about the EU, there is potential for maintaining diffuse support for the EU.

ZuZANA RINGLEROVA is an assistant professor at Masaryk University in the Czech Republic. She earned her PhD from Purdue University in the United States, where she worked on public support for the EU. She has published in European Union Politics and in the International Journal of Public Opinion Research. Her research focuses on public support for the EU and attitudes towards immigration.

\section{References}

Almond, G. A. and S. Verba. 1963. The Civic Culture; Political Attitudes and Democracy in Five Nations. Princeton, NJ: Princeton University Press, https://doi.org/10.1515/9781400874569.

Anderson, C. J. 1998. 'When in Doubt, Use Proxies-Attitudes toward Domestic Politics and Support for European Integration.' Comparative Political Studies 31 (5): 569-601, https://doi.org/10.1177/0010414098031005002.

Beaudonnet, L. and M. N. Franklin. 2014. 'Is There Diffuse Support for the European Project? The Eurozone Crisis as a Critical Test.' Paper presented at the Midwest Political Science Association 2014 Annual Meeting, Chicago.

Boomgaarden, H. G., A. R. T. Schuck, M. Elenbaas and C. H. de Vreese. 2011. 'Mapping EU Attitudes: Conceptual and Empirical Dimensions of Euroscepticism and EU Support.' European Union Politics 12 (2): 241-266, https://doi.org/10.1177/1465116510395411.

Bruter, M. 2009. 'Time Bomb? The Dynamic Effect of News and Symbols on the Political Identity of European Citizens.' Comparative Political Studies 42 (12): 1498-1536, https://doi.org/10.1177/0010414009332465.

Carey, S. 2002. 'Undivided Loyalties: Is National Identity an Obstacle to European Integration?' European Union Politics 3 (4): 387-413, https://doi.org/10.1177/1465116502003004001.

Carter, A. and R. L. Teten. 2002. 'Assessing Changing Views of the President: Revisiting Greenstein's Children and Politics.' Presidential Studies Quarterly 32 (3): 453-462, https://doi.org/10.1111/j.1741-5705.2002.tb00001.x.

Dalton, R. J. 2004. Democratic Challenges, Democratic Choices: The Erosion of Political Support 
in Advanced Industrial Democracies. New York: Oxford University Press, https://doi.org/10.1093/acprof:oso/9780199268436.003.0003.

de Vreese, C. 2004. 'The Effects of Strategic News on Political Cynicism, Issue Evaluations, and Policy Support: A Two-Wave Experiment.' Mass Communication and Society 7 (2): 191-214, https://doi.org/10.1207/s15327825mcs0702_4.

de Vreese, C. H. and H. G. Boomgaarden. 2005. 'Projecting EU Referendums-Fear of Immigration and Support for European Integration.' European Union Politics 6 (1): 59-82, https://doi.org/10.1177/1465116505049608.

de Vreese, C. H., H. G. Boomgaarden and H. A. Semetko. 2011. '(In)Direct Framing Effects: The Effects of News Media Framing on Public Support for Turkish Membership in the European Union.' Communication Research 38 (2): 179-205, https://doi.org/10.1177/0093650210384934.

Duchesne, S., E. Frazer, F. Haegel and V. Van Ingelgom. 2013. Citizens' Reactions to European Integration Compared: Overlooking Europe. New York: Palgrave Macmillan, https:// doi.org/10.1057/9781137297266.

Easton, D. 1965. A Systems Analysis of Political Life. New York: Wiley.

Eichenberg, R. C. and R. J. Dalton. 1993. 'Europeans and the European Communitythe Dynamics of Public Support for European Integration.' International Organization 47 (4): 507-534, https://doi.org/10.1017/S0020818300028083.

Eichenberg, R. C. and R. J. Dalton. 2007. 'Post-Maastricht Blues: The Transformation of Citizen Support for European Integration, 1973-2004.' Acta Politica 42 (2-3): 128-152, https://doi.org/10.1057/palgrave.ap.5500182.

Eurobarometer. 2015. 'Eurobarometer Interactive Search System.' Retrieved 7 July 2015 (http://ec.europa.eu/public_opinion/cf/index_en.cfm).

Gabel, M. 1998. 'Public Support for European Integration: An Empirical Test of Five Theories.' Journal of Politics 60 (2): 333-354, https://doi.org/10.2307/2647912.

Gabel, M. and H. D. Palmer. 1995. 'Understanding Variation in Public Support for European Integration.' European Journal of Political Research 27 (1): 3-19, https://doi.org/10.1111/j.1475-6765.1995.tb00627.x.

Hobolt, S. and J. Tilley. 2014. Blaming Europe? Responsibility without Accountability in the European Union. Oxford: Oxford University Press, https://doi.org/10.1093/acprof:oso/9780199665686.001.0001.

Hooghe, L. and G. Marks. 2004. 'Does Identity or Economic Rationality Drive Public Opinion on European Integration?' Ps-Political Science E Politics 37 (3): 415-420. https://doi.org/10.1017/S1049096504004585

Kopecký, P. and C. Mudde. 2002. 'The Two Sides of Euroscepticism: Party Positions on European Integration in East Central Europe.' European Union Politics 3 (3): 297-326, https://doi.org/10.1177/1465116502003003002.

Lindberg, L. and S. Scheingold. 1970. Europe's Would-Be Polity: Patterns of Change in the European Community. Englewood Cliffs, NJ: Prentice-Hall.

Long, J. Scott. 1997. Regression Models for Categorical and Limited Dependent Variables, Advanced Quantitative Techniques in the Social Sciences 7. Thousand Oaks, CA: Sage Publications.

Mahler, V. A., B. J. Taylor and J. R. Wozniak. 2000. 'Economics and Public Support for the European Union: An Analysis at the National, Regional, and Individual Levels.' Polity 32 (3): 429-453, https://doi.org/10.2307/3235360.

McLaren, L. M. 2002. 'Public Support for the European Union: Cost/Benefit Analysis or Perceived Cultural Threat?' Journal of Politics 64 (2): 551-566, https://doi.org/10.1111/1468-2508.00139.

Norris, P. 1999. Critical Citizens: Global Support for Democratic Government. New York: Oxford University Press. 
Norris, P. 2011. Democratic Deficit: Critical Citizens Revisited. New York: Cambridge University Press.

Ringlerova, Z. 2015. 'Weathering the Crisis: Evidence of Diffuse Support for the EU from a Six-Wave Dutch Panel.' European Union Politics 16 (4): 558-576, https://doi.org/10.1177/1465116515588964.

Serricchio, F., M. Tsakatika and L. Quaglia. 2013. 'Euroscepticism and the Global Financial Crisis.' Jcms-Journal of Common Market Studies 51 (1): 51-64, https:// doi.org/10.1111/j.1468-5965.2012.02299.x.

Taggart, P. and A. Szczerbiak. 2004. 'Contemporary Euroscepticism in the Party Systems of the European Union Candidate States of Central and Eastern Europe.' European Journal of Political Research 43 (1): 1-27, https://doi.org/10.1111/j.1475-6765.2004.00143.x.

Torcal, M., J. Muñoz and E. Bonet. 2012. 'Trust in the European Parliament: From Affective Heuristics to Rational Cueing.' Pp. 140-167 in Citizens and the European Polity Mass Attitudes Towards the European and National Polities, edited by D. Sanders, P. C. Magalhaes and Gábor Tóka. Oxford: Oxford University Press, https://doi.org/10.1093/acprof:oso/9780199602339.003.0007.

Zaller, J. 1992. The Nature and Origins of Mass Opinion. Cambridge: Cambridge University Press, https://doi.org/10.1017/CBO9780511818691. 


\section{Appendix}

Table A. Randomisation checks

\begin{tabular}{|c|c|c|c|}
\hline & Control & Treatment & Total \\
\hline \multicolumn{4}{|l|}{ Gender } \\
\hline Male & 50 & 46 & 96 \\
\hline Female & 55 & 52 & 107 \\
\hline Total & 105 & 98 & 203 \\
\hline \multicolumn{4}{|l|}{ Age } \\
\hline $18-24$ & 15 & 10 & 25 \\
\hline $25-34$ & 47 & 42 & 89 \\
\hline $35-44$ & 18 & 27 & 45 \\
\hline $45-54$ & 12 & 10 & 22 \\
\hline $55<$ & 12 & 7 & 19 \\
\hline Total & 104 & 96 & 200 \\
\hline \multicolumn{4}{|l|}{ Education } \\
\hline No high school & 1 & 1 & 2 \\
\hline High school & 21 & 18 & 39 \\
\hline Some college & 11 & 11 & 22 \\
\hline College & 72 & 67 & 139 \\
\hline Total & 105 & 97 & 202 \\
\hline \multicolumn{4}{|c|}{ Political interest (national) } \\
\hline Never & 6 & 6 & 12 \\
\hline Sometimes & 57 & 56 & 113 \\
\hline Often & 41 & 34 & 75 \\
\hline Total & 104 & 96 & 200 \\
\hline \multicolumn{4}{|c|}{ Political interest (EU) } \\
\hline Never & 25 & 17 & 42 \\
\hline Sometimes & 61 & 67 & 128 \\
\hline Often & 15 & 10 & 25 \\
\hline Total & 101 & 94 & 195 \\
\hline \multicolumn{4}{|l|}{ Ideology } \\
\hline Left & 21 & 20 & 41 \\
\hline Centre & 42 & 37 & 79 \\
\hline Right & 35 & 34 & 69 \\
\hline Total & 98 & 91 & 189 \\
\hline
\end{tabular}


Sociologický časopis/Czech Sociological Review, 2019, Vol. 55, No. 3

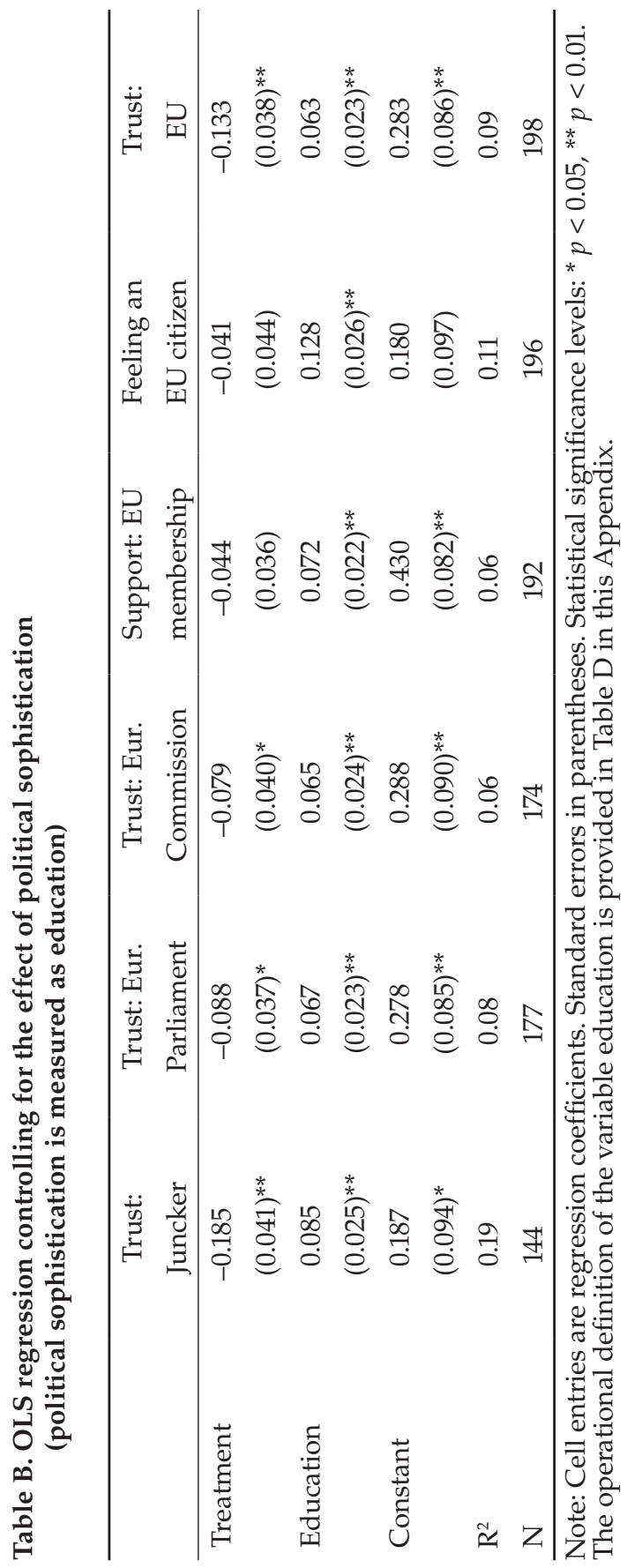




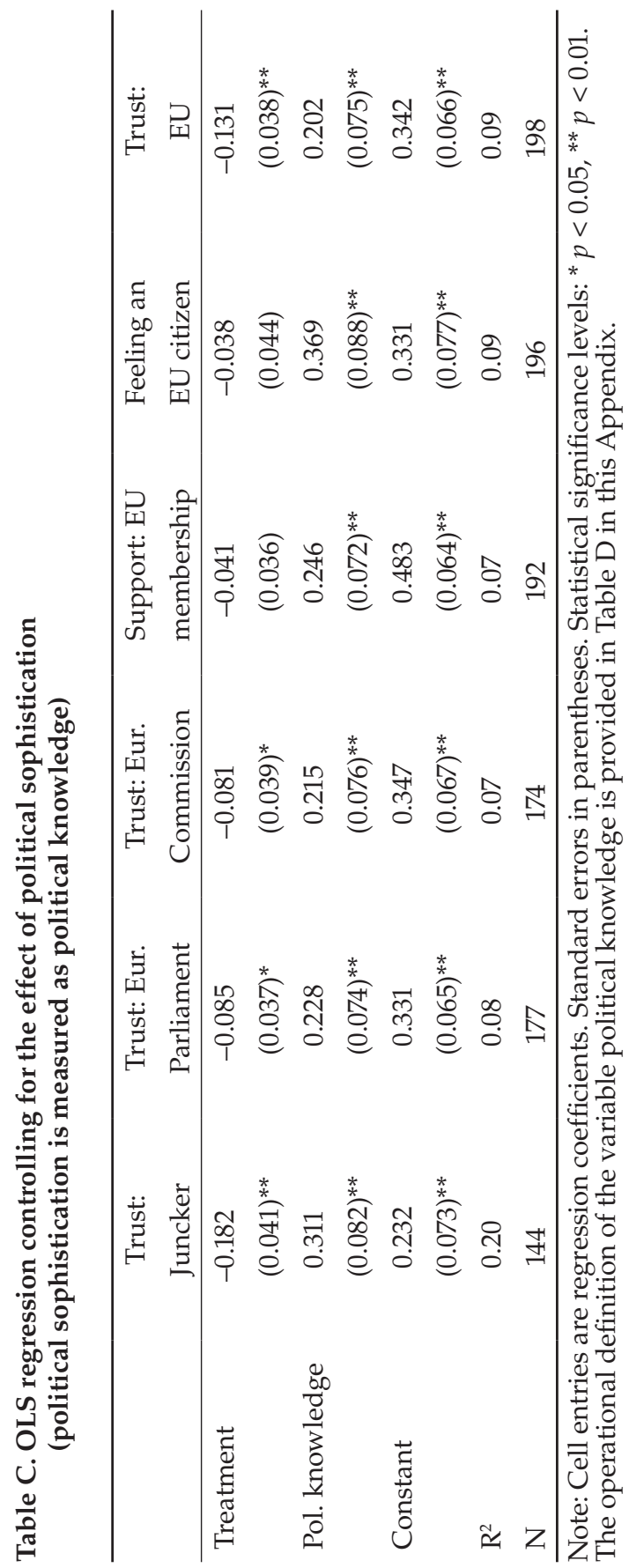


Table D. Definitions of additional independent variables

\begin{tabular}{|c|c|}
\hline Variable name & Description \\
\hline Education & $\begin{array}{l}\text { Recoded from survey question } 14 \text { into the following four ca- } \\
\text { tegories: } 1 \text { 'No high school', } 2 \text { 'High school', } 3 \text { 'Some college', } \\
4 \text { 'College'. }\end{array}$ \\
\hline Political knowledge & $\begin{array}{l}\text { Based on question } 13 \text { of the questionnaire. Correct answers to } \\
\text { items in question } 13 \text { were coded as } 1 \text {, incorrect answers were } \\
\text { coded } 0 \text {. The political knowledge variable is a mean index } \\
\text { composed of these three items. The index ranges between } \\
0 \text { and } 1.1 \text { indicates high knowledge, } 0 \text { indicates low knowledge. }\end{array}$ \\
\hline Age & Respondents' age in years. \\
\hline Ideology & Based on survey question 11. \\
\hline $\begin{array}{l}\text { Interest in national } \\
\text { political matters }\end{array}$ & $\begin{array}{l}\text { Based on the first item in survey question } 12 \text {. Coded as follows: } \\
0 \text { 'Never', } 1 \text { 'Sometimes', } 2 \text { 'Often'. }\end{array}$ \\
\hline $\begin{array}{l}\text { Interest in European } \\
\text { political matters }\end{array}$ & $\begin{array}{l}\text { Based on the second item in survey question } 12 \text {. Coded as fol- } \\
\text { lows: } 0 \text { 'Never', } 1 \text { 'Sometimes', } 2 \text { 'Often'. }\end{array}$ \\
\hline Gender & 0 male, 1 female \\
\hline
\end{tabular}

Table E. OLS regression: the moderating effect of age

\begin{tabular}{lcccccc}
\hline & $\begin{array}{c}\text { Trust: } \\
\text { Juncker }\end{array}$ & $\begin{array}{c}\text { Trust: Eur. } \\
\text { Parliament }\end{array}$ & $\begin{array}{c}\text { Trust: } \\
\text { EC }\end{array}$ & $\begin{array}{c}\text { Trust: } \\
\text { EU }\end{array}$ & $\begin{array}{c}\text { Support: } \\
\text { Member- } \\
\text { ship }\end{array}$ & $\begin{array}{c}\text { Feeling an } \\
\text { EU citizen }\end{array}$ \\
\hline Treatment & -0.160 & -0.143 & -0.070 & -0.311 & -0.028 & -0.078 \\
& $(0.130)$ & $(0.118)$ & $(0.122)$ & $(0.125)^{*}$ & $(0.121)$ & $(0.148)$ \\
Age & -0.007 & -0.009 & -0.008 & -0.008 & -0.006 & -0.009 \\
& $(0.002)^{* *}$ & $(0.002)^{* * *}$ & $(0.002)^{* *}$ & $(0.002)^{* *}$ & $(0.002)^{* *}$ & $(0.002)^{* *}$ \\
Treatment*Age & -0.001 & 0.002 & -0.000 & 0.005 & -0.000 & 0.001 \\
& $(0.003)$ & $(0.003)$ & $(0.003)$ & $(0.003)$ & $(0.003)$ & $(0.004)$ \\
Constant & 0.751 & 0.831 & 0.800 & 0.807 & 0.893 & 0.953 \\
& $(0.081)^{* *}$ & $(0.071)^{* *}$ & $(0.076)^{* *}$ & $(0.076)^{* *}$ & $(0.074)^{* *}$ & $(0.090)^{* *}$ \\
$\mathrm{R}^{2}$ & 0.23 & 0.17 & 0.15 & 0.14 & 0.08 & 0.10 \\
$\mathrm{~N}$ & 142 & 174 & 171 & 195 & 189 & 193 \\
\hline
\end{tabular}

Note: Cell entries are regression coefficients. Standard errors in parentheses. Statistical significance levels: ${ }^{*} p<0.05,{ }^{* *} p<0.01$. 
Table F. OLS regression: the moderating effect of gender

\begin{tabular}{lcccccc}
\hline & $\begin{array}{c}\text { Trust: } \\
\text { Juncker }\end{array}$ & $\begin{array}{c}\text { Trust: Eur. } \\
\text { Parliament }\end{array}$ & $\begin{array}{c}\text { Trust: } \\
\text { EC }\end{array}$ & $\begin{array}{c}\text { Trust: } \\
\text { EU }\end{array}$ & $\begin{array}{c}\text { Support: } \\
\text { Member- } \\
\text { ship }\end{array}$ & $\begin{array}{c}\text { Feeling an } \\
\text { EU citizen }\end{array}$ \\
\hline Treatment & -0.125 & -0.062 & -0.033 & -0.104 & -0.053 & -0.081 \\
Gender & $(0.060)^{*}$ & $(0.054)$ & $(0.057)$ & $(0.056)$ & $(0.054)$ & $(0.067)$ \\
& 0.094 & 0.068 & 0.114 & 0.016 & -0.040 & -0.077 \\
Treat.* Gender & $(0.061)$ & $(0.054)$ & $(0.057)^{*}$ & $(0.054)$ & $(0.053)$ & $(0.064)$ \\
& -0.131 & -0.061 & -0.104 & -0.056 & 0.015 & 0.078 \\
Constant & $(0.085)$ & $(0.077)$ & $(0.080)$ & $(0.078)$ & $(0.075)$ & $(0.093)$ \\
& 0.442 & 0.482 & 0.463 & 0.497 & 0.703 & 0.667 \\
$\mathrm{R}^{2}$ & $(0.043)^{* *}$ & $(0.038)^{* *}$ & $(0.040)^{* *}$ & $(0.039)^{* *}$ & $(0.037)^{* *}$ & $(0.046)^{* *}$ \\
$\mathrm{~N}$ & 0.14 & 0.04 & 0.05 & 0.06 & 0.01 & 0.01 \\
\hline & 144 & 177 & 174 & 198 & 192 & 196 \\
\hline
\end{tabular}

Note: Cell entries are regression coefficients. Standard errors in parentheses. Statistical significance levels: * $p<0.05,{ }^{* *} p<0.01$.

Table G. OLS regression: the moderating effect of left-right ideology

\begin{tabular}{lcccccc}
\hline & $\begin{array}{c}\text { Trust: } \\
\text { Juncker }\end{array}$ & $\begin{array}{c}\text { Trust: Eur. } \\
\text { Parliament }\end{array}$ & $\begin{array}{c}\text { Trust: } \\
\text { EC }\end{array}$ & $\begin{array}{c}\text { Trust: } \\
\text { EU }\end{array}$ & $\begin{array}{c}\text { Support: } \\
\text { Member- } \\
\text { ship }\end{array}$ & $\begin{array}{c}\text { Feeling an } \\
\text { EU citizen }\end{array}$ \\
\hline Treatment & -0.008 & -0.008 & 0.053 & -0.018 & 0.098 & 0.122 \\
& $(0.152)$ & $(0.139)$ & $(0.145)$ & $(0.142)$ & $(0.137)$ & $(0.167)$ \\
Ideology & 0.027 & 0.022 & 0.035 & 0.015 & 0.021 & 0.027 \\
& $(0.018)$ & $(0.016)$ & $(0.017)^{*}$ & $(0.017)$ & $(0.016)$ & $(0.020)$ \\
Treat.*Ideology & -0.034 & -0.016 & -0.025 & -0.021 & -0.025 & -0.027 \\
& $(0.025)$ & $(0.023)$ & $(0.024)$ & $(0.023)$ & $(0.023)$ & $(0.028)$ \\
Constant & 0.344 & 0.400 & 0.330 & 0.430 & 0.576 & 0.490 \\
& $(0.108)^{* *}$ & $(0.099)^{* *}$ & $(0.103)^{* *}$ & $(0.101)^{* *}$ & $(0.097)^{* *}$ & $(0.116)^{* *}$ \\
$\mathrm{R}^{2}$ & 0.16 & 0.05 & 0.06 & 0.07 & 0.02 & 0.01 \\
$\mathrm{~N}$ & 136 & 167 & 165 & 187 & 182 & 184 \\
\hline
\end{tabular}

Note: Cell entries are regression coefficients. Standard errors in parentheses. Statistical significance levels: ${ }^{* *} p<0.01$. 
Table H. OLS regression: the moderating effect of interest in national political matters

\begin{tabular}{lcccccc}
\hline & $\begin{array}{c}\text { Trust: } \\
\text { Juncker }\end{array}$ & $\begin{array}{c}\text { Trust: } \\
\text { EP }\end{array}$ & $\begin{array}{c}\text { Trust: } \\
\text { EC }\end{array}$ & $\begin{array}{c}\text { Trust: } \\
\text { EU }\end{array}$ & $\begin{array}{c}\text { Support: } \\
\text { Member- } \\
\text { ship }\end{array}$ & $\begin{array}{c}\text { Feeling an } \\
\text { EUtizen }\end{array}$ \\
\hline Treatment & -0.036 & -0.048 & -0.037 & -0.094 & 0.022 & 0.105 \\
Interest & $(0.113)$ & $(0.103)$ & $(0.107)$ & $(0.100)$ & $(0.098)$ & $(0.117)$ \\
& 0.121 & 0.067 & 0.081 & 0.065 & 0.037 & 0.094 \\
Treat.*Interest & $(0.056)^{*}$ & $(0.051)$ & $(0.053)$ & $(0.049)$ & $(0.048)$ & $(0.056)$ \\
& -0.111 & -0.026 & -0.028 & -0.026 & -0.050 & -0.109 \\
Constant & $(0.076)$ & $(0.069)$ & $(0.073)$ & $(0.069)$ & $(0.067)$ & $(0.081)$ \\
& 0.321 & 0.420 & 0.405 & 0.414 & 0.631 & 0.499 \\
$\mathrm{R}^{2}$ & $(0.085)^{* * *}$ & $(0.077)^{* *}$ & $(0.081)^{* *}$ & $(0.072)^{* *}$ & $(0.073)^{* * *}$ & $(0.083)^{* *}$ \\
$\mathrm{~N}$ & 0.16 & 0.04 & 0.04 & 0.07 & 0.01 & 0.02 \\
\hline
\end{tabular}

Note: Cell entries are regression coefficients. Standard errors in parentheses. Statistical significance levels: ${ }^{*} p<0.05,{ }^{* *} p<0.01$.

Table I. OLS regression: the moderating effect of interest in European political matters

\begin{tabular}{lcccccc}
\hline & $\begin{array}{c}\text { Trust: } \\
\text { Juncker }\end{array}$ & $\begin{array}{c}\text { Trust: } \\
\text { EP }\end{array}$ & $\begin{array}{c}\text { Trust: } \\
\text { EC }\end{array}$ & $\begin{array}{c}\text { Trust: } \\
\text { EU }\end{array}$ & $\begin{array}{c}\text { Support: } \\
\text { Member- } \\
\text { ship }\end{array}$ & $\begin{array}{c}\text { Feeling an } \\
\text { EU citizen }\end{array}$ \\
\hline Treatment & -0.156 & -0.125 & -0.135 & -0.144 & -0.070 & -0.026 \\
Interest & $(0.092)$ & $(0.080)$ & $(0.084)$ & $(0.076)$ & $(0.075)$ & $(0.089)$ \\
& 0.048 & 0.010 & 0.025 & 0.041 & 0.005 & 0.066 \\
Treat.*Interest & $(0.052)$ & $(0.048)$ & $(0.050)$ & $(0.046)$ & $(0.045)$ & $(0.053)$ \\
& -0.028 & 0.044 & 0.059 & 0.020 & 0.028 & -0.009 \\
Constant & $(0.083)$ & $(0.072)$ & $(0.075)$ & $(0.070)$ & $(0.069)$ & $(0.082)$ \\
& 0.444 & 0.504 & 0.494 & 0.463 & 0.678 & 0.568 \\
$\mathrm{R}^{2}$ & $(0.061)^{* *}$ & $(0.056)^{* *}$ & $(0.058)^{* *}$ & $(0.051)^{* *}$ & $(0.050)^{* *}$ & $(0.059)^{* * *}$ \\
$\mathrm{~N}$ & 0.12 & 0.03 & 0.04 & 0.06 & 0.01 & 0.02 \\
\hline Note: Cell & 139 & 171 & 167 & 191 & 185 & 189 \\
\hline
\end{tabular}

Note: Cell entries are regression coefficients. Standard errors in parentheses. Statistical significance levels: ${ }^{*} p<0.05,{ }^{* *} p<0.01$. 